\title{
Tornar-se Professor: A Constituição dos Saberes Profissionais de Professores Indígenas Tuparí
}

\author{
Becoming Teacher: The Constitution of the Professional \\ Knowledge of Tuparí Indigenous Teachers
}

Wany Bernardete de Araujo Sampaio ${ }^{1}$

Edineia Aparecida Isidoro ${ }^{2}$

Luciana Castro de Paula ${ }^{3}$

Recebido em fevereiro de 2018

Aceito em maio de 2018

\section{Resumo}

Este estudo tem como objetivo dar voz a professores indígenas, estimulando-lhes uma reflexão acerca da construção de saberes em sua prática docente. Analisa-se como e quando esses saberes são construidos, observando-se a organização didática em classes multisseriadas, os materiais didáticos utilizados e o ensino das línguas indígenas. Os resultados da análise mostram que nas reflexões feitas por professores indígenas sobre as questões em pauta há uma valorização de sua formação acadêmica inicial, embora nelas esteja presente mais fortemente a importância de suas experiências discentes, docentes e comunitárias.

Palavras-chave: Formação de professores indígenas. Construção de saberes. Saberes docentes. Prática docente. Professores Tuparí.

\footnotetext{
Abstract

This study aims to give voice to indigenous teachers, stimulating thir reflection about the construction of their knowledge in their teaching practice. It is analyzed how and when

${ }^{1}$ Doutora em Linguística (UNIR). Doutora em Educação Escolar (UNESP). Professora aposentada da Fundação Universidade Federal de Rondônia - UNIR, Departamento de Línguas Vernáculas, Campus de Porto Velho. Professora Formadora do Programa Ação Saberes Indígenas na Escola, Departamento de Educação Intercultural - UNIR (2014/2017), Campus de Ji-Paraná. Pesquisadora do Grupo de Estudos em Culturas, Educação e Linguagens - GECEL/UNIR/CNPq, Campus de Porto Velho. wansamp@gmail.com.

${ }^{2}$ Mestre em Socioliguística (Universidade Federal de Goiânia). Doutoranda em Linguística (UnB). Professora do Curso de Licenciatura em Educação Básica Intercultural, da Universidade Federal de Rondônia - UNIR, Departamento de Educação Intercultural, na área de Linguagem. edineiapi@yahoocom.br.

${ }^{3}$ Mestre em Ciências Sociais (UNESP). Doutoranda em Antropologia (PPGA-UFPA). Professora do Departamento de Educação Intercultural da Universidade Federal de Rondônia. Pesquisadora do Laboratório de Línguas e Culturas Indígenas (LALIC-UNIR) e do Grupo de Pesquisa em Educação na Amazônia (GPEA-UNIR).
} 
the knowledge is constructed, observing the didactic organization in multi-serials classes, the didactic materials used, and the teaching of the indigenous languages. The results of the analysis show that in the reflections made by indigenous teachers on the issues at hand there is an appreciation of their academic formation, although they highlight the importance of their experience as students and teachers, as well as their social life in their respective communities.

Keywords: Indigenous teachers training. Knowledge construction. Teaching knowledge. Teaching practice. Tuparí teachers.

No presente trabalho temos dois objetivos principais: o primeiro deles é dar voz aos professores indígenas. Nesse sentido, o texto apresenta-se prenhe de suas falas, porque é a partir delas que podemos ter acesso ao pensamento desses professores e as suas buscas e reflexões sobre o cenário educacional em que estão inseridos; o segundo objetivo é estimular nos pesquisadores e professores formadores uma reflexão acerca da constituição dos saberes dos professores indígenas a partir do trabalho docente por eles vivenciado. Para tanto, a reflexão proposta tem por base entrevistas realizadas com professores indígenas alfabetizadores, professores indígenas orientadores de estudo e pesquisadores indígenas pertencentes à etnia Tuparí, participantes do programa nacional $A c ̧ a ̃ o$ Saberes Indígenas na Escola (MEC/SECADI) ${ }^{4}$, desenvolvido pela Universidade Federal de Rondônia - UNIR, no campus de Ji-Paraná5. As entrevistas foram

\footnotetext{
${ }^{4}$ A Ação Saberes Indígenas na Escola é regulamentada e tem diretrizes complementares definidas pela Portaria $\mathrm{n}^{\circ}$ 98, de 6 de dezembro de 2013 (MEC/SECADI). Integrando o "Eixo Pedagogias Diferenciadas e o Uso das Línguas Indígenas do Programa Nacional dos Territórios Etnoeducacionais Indígenas" (PORTARIA n ${ }^{\circ} 98$, Art. $1^{\circ}, \S 1^{\circ}$ ), a Ação é desenvolvida nacionalmente "em regime de colaboração com os estados, o Distrito Federal, os municípios e as instituições de ensino superior e baseada nos princípios da especificidade, da organização comunitária, do multilinguismo e da interculturalidade, assegurados pelo art. $210, \S 2^{\circ}$, da Constituição Federal" (PORTARIA n ${ }^{\circ}$ 98, Art. $1^{\circ}, \S 1^{\circ}$ ).

${ }^{5}$ Rondônia coordena a rede Rondônia/Acre. Em Rondônia, a Ação Saberes Indígenas na Escola é desenvolvida pela UNIR, através do Curso de Licenciatura Intercultural, Departamento de Educação Intercultural, no campus de Ji-Paraná; a SEDUC conta com uma coordenação estadual. Na Universidade, a equipe é constituída por uma coordenação geral (da rede $\mathrm{RO} / \mathrm{AC}$ ), uma coordenação adjunta (núcleo de Rondônia), seis professores formadores, seis professores conteudistas, dois supervisores; com relação aos indígenas, participam: sete pesquisadores e sete orientadores de estudo, além de 60 professores alfabetizadores, sendo: 16 na TI Rio Branco, 33 na TI Igarapé Lourdes e 11 na TI Rio Guaporé. Foram beneficiários diretos, em 2014, indígenas pertencentes às etnias Gavião, Arara, Djeoromitxi, Makurap e Tuparí. A Ação Saberes Indígenas na Escola, em Rondônia, abrange três Terras Indígenas: T.I. Igarapé Lourdes (Ji-Paraná), T.I. Rio Guaporé (GuajaráMirim), e T.I. Rio Branco (Alta Floresta do Oeste, São Francisco e São Miguel do Guaporé). (Dados referentes a 2014 - Relatório Final 2014).
} 
realizadas e gravadas em vídeo pelos Professores Edineia Aparecida Isidoro (Coordenadora da Rede RO/AC), Luciana Castro (Coordenadora do Núcleo de Rondônia), Rozane Alonso Alves (Supervisora da Ação/2014) e Jonatha Daniel dos Santos (Formador Conteudista/2014), no ano de 2014 e, no ano de 2016, a transcrição das entrevistas foi efetuada pela Professora Wany Bernardete de Araujo Sampaio (Professora Formadora do Programa Ação Saberes Indígenas na Escola).

Colaboraram com este trabalho, concedendo as entrevistas, os seguintes professores: Edilson Tuparí e Maurício Tuparí (Aldeia Bom Jesus); Geovane Tuparí (Aldeia Trindade); Isaías Tuparí (Aldeia Colorado); Juari Tuparí (Aldeia Serrinha); Morais Tuparí (Aldeia Poção-Morro Pelado); Raul Tuparí (Aldeia Nova Esperança - trabalha na Aldeia Trindade).

Considerando as falas dos professores entrevistados, buscamos sistematizar e discutir alguns aspectos concernentes ao trabalho docente nas escolas indígenas Tuparí: (i) a organização didática em classes multisseriadas; (ii) os materiais didáticos utilizados pelos professores; (iii) o ensino da língua indígena na escola. Nossa discussão sobre os temas evidenciados toma por suporte a concepção de que "os fundamentos do ensino são, a um só tempo, existenciais, sociais e pragmáticos" (Tardif e Raymond 2000, p. 235). Na construção dos seus saberes profissionais, o professor conta com a sua experiência de vida, com várias fontes sociais, tais como a família, a escola, a universidade e também com a sua própria prática docente. Portanto, em nossa análise, buscamos perceber como/quando esses saberes se constituem, considerando-se a tripla caracterização (existencial, social e pragmática) dos saberes docentes, bem como a sua dimensão temporal.

O texto está organizado em duas seções: na primeira, apresentamos algumas informações sobre os Tuparí, sua localização e situação sociolinguística nas suas escolas; na segunda seção, trazemos para a discussão as vozes dos professores indígenas entrevistados, considerando os aspectos evidenciados em seus depoimentos.

\section{Quem são os Tuparí}

Os Tuparí são indígenas habitantes do estado de Rondônia, falantes da língua Tuparí, da Família Tuparí, Tronco Tupí (Rodrigues 1986). Informações históricas sobre os Tuparí atestam que:

Há estimativas de que houvesse cerca de 3 mil Tuparí no início do século XX. O etnólogo Franz Caspar supôs que tenham visto o homem branco pela primeira vez na década de 1920. [...]. O primeiro etnólogo a visitá-los foi Snethlage, em 1934, quando encontrou apenas 250 indivíduos. Caspar, em 1948, registrou 200 [...]. Quando Franz Caspar voltou ao Brasil e visitou o grupo, em 1955, encontrou-os reduzidos a 
apenas 66 pessoas por conta de uma epidemia de sarampo que assolara a aldeia no ano anterior. Foi apenas em 1980 que a FUNAI (órgão indigenista que substituiu o SPI a partir de 1967) instalou um Posto Indígena na região do rio Branco e que os direitos territoriais dos Tuparí e dos outros povos vizinhos começaram a ser reconhecidos pelo Estado brasileiro [...] Mesmo depois de décadas de contato, foi apenas em 1987 que alguns Tuparí conheceram uma cidade [...]. (http://pib. socioambiental.org/pt/povo/Tuparí/1088)

Franz Caspar (1953) detalhou com maestria e sensibilidade os Tuparí em suas malocas. Ele conviveu com os Tuparí, observou e vivenciou sua cultura e a descreveu com riqueza de detalhes. A leitura de seu livro é um mergulho na vida dos Tuparí daquele período. Para ilustrar, transcrevemos a descrição feita por Caspar quando da primeira vez que entrou em uma moradia Tuparí:

Entramos pela porta baixa, meio encoberta por folhas de palmentira. A princípio, nada vi no aposento sem janelas. Lentamente, meus olhos se acostumaram à semi-obscuridade. No meio da choça, erguia-se uma parede de esteira que escondia metade da habitação. No centro, enfileiravam-se uma porção de recipientes de barro, cujos fundos pontudos estavam enterrados no solo. Ao longo da paredeteto abobadada estavam pendradas as redes dos moradores. Pequenas fogueiras iluminavam três índias nuas que nos olharam curiosas (Caspar 1953: 73).

A antropóloga Denise Maldi Meireles (1989: 127) registra:

[...] O arqueólogo Eurico Miller (1983), realizando pesquisa no altomédio Guaporé, concluiu que, nesta região, grupos de agricultores ceramistas oriundos da região de Rondônia teriam atingido as margens do rio cerca de AD 900 [...]. Combinando dados arqueológicos com dados linguísticos, ele concluiu ainda que os primeiros grupos seriam falantes do tronco Tupí, pertencentes à família Tuparí, de língua guaratägaja.

Atualmente não temos notícias da existência dos povos de língua guaratägaja em Rondônia, porém esse registro é importante, visto que, historicamente, se pode constatar que a presença dos Tuparí nessa região parece ser bastante antiga.

Embora disponhamos da etnografia de Caspar e outros escritos sobre o Tuparí, podemos considerar que, assim como acontece em relação à maioria dos povos indígenas de Rondônia, não há muitos estudos históricos, etnográficos, antropológicos e linguísticos sobre os Tuparí. A esse respeito, o antropólogo Felipe Ferreira Vander Velden (2010) afirma: 
Os pequenos grupos Tupí localizados na bacia do rio Guaporé Tuparí, Makuráp, Wayurú, Sakyrabiát, Akuntsú (família Tuparí) e Aruá (família Mondé) são ainda menos conhecidos pela etnologia. Franz Caspar nos legou preciosas descrições dos Tuparí nos anos de 1950 (Caspar 1952, 1953a), e uma monografia de grande relevância para o conhecimento deste povo (Caspar 1975), além de vários artigos (Caspar 1953b, 1955a, 1955b, 1956-58, 1976[1957]) que, inclusive, fazem menção a outros povos vizinhos dos Tuparí. Emilia Snethlage $(1937,1939)$ também deixou uns poucos materiais sobre esses grupos, vários deles de reduzida população atualmente. Depois dela tivemos apenas mitos Tuparí coletados por Betty Mindlin (1993b), que também organizou um volume de mitos recolhidos entre grupos Tupí e nãoTupí na região do Guaporé (Mindlin 1995b; ver também Mindlin 2006b, 2010); o artigo seminal de Denise Meireles (1991) a respeito do "complexo do marico" (um tipo de cesto) - que inclui os povos não-Tupí na região; e a recente dissertação de mestrado de Nicole Pinto (2009) sobre os Wayurú. (Vander Velden, F. F., 2010: 125-126).

O antropólogo Júlio Cezar Melatti (2011), em seus escritos sobre as Áreas Etnográficas da América Indígena Mamoré-Guaporé, registra que:

Apesar de o rio Guaporé ter começado a ser explorado no início do século XVIII, o grande impacto que os índios da área sofreram foi a partir do "boom" da borracha, na passagem do século XIX para o XX. Em 1948, quando Franz Caspar visitou pela primeira vez a região, os Tuparís eram, dos índios então conhecidos, os que ainda mantinham uma certa autonomia com relação aos seringais, estando os demais trabalhando neles e bastante dizimados pelas moléstias introduzidas pelo contato. Os próprios Tuparís, no intervalo entre a primeira e a segunda visita de Caspar, poucos anos depois, sofreram pesada perda populacional, caindo de cerca de 200 para 66 pessoas, devido a uma epidemia de sarampo e a outras moléstias (Mindlin 1993: 15-16). Os Tuparís continuam a ser os únicos índios da área a disporem de uma substancial etnografia publicada. Infelizmente, só foi traduzido para o português o livro de viagem de Caspar (1958); o outro (1975), mais etnográfico, continua em alemão. A coletânea de mitos Tuparís publicada por Betty Mindlin (1993), além das próprias narrativas, traz mais um atrativo que é a possibilidade de comparar fotos de Caspar, tomadas em 1948 e 1955, que republica, com as fotos de Lucia Mindlin Loeb, tiradas nos anos 1980, sendo que alguns Tuparís estão retratados tanto nas fotos mais antigas como nas mais recentes (Melatti 2011: 01).

Devemos destacar alguns recentes trabalhos sobre os Tuparí, como a 
Dissertação de Mestrado de Mary Gonçalves Fonseca (2011), Casa de escrever no papeo: a escola Tuparí da Terra Indígena Rio Branco, Rondônia, em que a autora, no capítulo 2 , enfoca o contato, a luta pela terra e o contexto sociocultural em que se insere a escola Tuparí.

Há, também, relevantes trabalhos de estudo linguísticos, dentre eles a Dissertação de Mestrado e a Tese de Doutorado de Poliana Maria Alves (1991, 2004): o primeiro estuda a fonologia da língua Tuparí e o segundo trata-se de um dicionário bilíngue Tuparí/português que traz um resumo da gramática Tuparí. Não podemos esquecer das contribuições da professora Lucy Seki, com o texto Aspectos Morfossintáticos do Nome em Tuparí (2002) e também organizou um livro de alfabetização Tupari 'Ema'ẽ, que até pouco tempo era o único material específico para a alfabetização na língua Tuparí. Um importante trabalho foi Versuch einer Grammatik der Tupari-Sprache, cujos dados foram levantados por Franz Caspar na década de 1950, organizado por Rodrigues e publicado em alemão em 1957. Esse trabalho foi publicado em português, no ano de 2017, com o título Esboço da Gramática da Língua Tuparí pelo Laboratório de Línguas e Literaturas Indígenas da Universidade de Brasília. Brevemente teremos outros trabalho resultados de pesquisas de doutorado em andamento.

Atualmente, os Tuparí vivem em várias aldeias distribuídas em duas Terras Indígenas (TI): a TI Rio Branco e a TI Rio Guaporé. Todas as aldeias e escolas em que atuam os professores que contribuíram com o presente trabalho pertencem à TI Rio Branco, que está localizada em uma região abrangida por três municípios: Alta Floresta do Oeste, São Miguel do Guaporé e São Francisco do Guaporé; os indígenas têm maior relacionamento com o município de Alta Floresta, onde podem contar com serviços de saúde e educação (Isidoro et al. 2014).

Segundo informações da ONG Kanindé (on line) ${ }^{6}$, no ano de 2005 havia 329 índios Tuparí na TI Rio Branco, distribuídos em 13 aldeias: Serrinha, Trindade, Nazaré, Colorado, Encrenca, Cajuí, Estaleiro, Morro Pelado, Manduca, Castilho, Palhal, Bom Jesus e São Luís.

Em 2015, Raul Tuparí, em seu Trabalho de Conclusão de Curso de Licenciatura Intercultural, registrou uma população de cerca de 700 pessoas distribuídas em 29 aldeias: Bom Jesus, Bom Amigo, São Luís, Bom Paraíso, Samba, Barranco Alto, Barreiro de Arara, Boa Esperança, Morada Nova, Nova Esperança, Serrinha, Trindade, Nazaré, Terra Nova, Bom Sossego, Bananeira, Jatobá, Tucumã, Colorado, Encrenca, Castilho, Cajuí II, Cajuí I, Estaleiro, Poção, Morro Pelado, Formigueiro, Palhal, Arikapú. Este aumento de aldeias se deve, segundo o professor Raul, principalmente, ao fato de as famílias procurarem se instalar o mais próximo possível à estrada, para poderem ter mais acesso à escola, à saúde e ao município de Alta Floresta.

${ }^{6} \mathrm{http}: / /$ pib.socioambiental.org/pt/povo/Tuparí/1087 
A TI Rio Branco concentra um grande número de povos e línguas em contato: Tuparí, Djeoromitxí, Makuráp, Aruá, Ajurú (Wajuru), Arikapú, Kampé, Sakyrabiát, Jahói. Alguns destes povos não falam mais sua língua, como é o caso dos Kampé, com apenas um falante. Outros, como os Aruá e os Makuráp, estão em acelerado processo de perda linguística, dado que as línguas não estão mais sendo ensinadas às crianças no espaço familiar. A língua Tuparí é dominante: é a língua falada em várias aldeias e entendida por quase todos os povos que convivem na TI Rio Branco (Sampaio, Isidoro e Paula 2014).

No que tange à educação escolar, professores indígenas atuam até o quinto ano do Ensino Fundamental; do sexto ao nono ano, professores não indígenas lecionam a maioria das disciplinas. O Ensino Médio foi implantado recentemente e ainda é muito incipiente. Muitos jovens Tuparí e de outras etnias se deslocam até o município de Alta Floresta para concluírem seus estudos. Há uma grande demanda de jovens para ingressar na universidade (Isidoro et al. 2014).

\section{As vozes dos professores Tuparí}

Nesta seção, trazemos as vozes dos professores indígenas entrevistados, as quais nos serviram como elemento motivador e objeto de estudos para a discussão proposta. Todos os professores colaboradores habitam aldeias localizadas na Terra Indígena Rio Branco. São eles: Edilson Tuparí (Aldeia Bom Jesus); Maurício Tuparí (Aldeia Bom Jesus); Geovane Tuparí (Aldeia Trindade); Isaías Tuparí (Aldeia Colorado); Juari Tuparí (Aldeia Serrinha); Morais Tuparí (Aldeia Poção-Morro Pelado); Raul Tuparí (mora na Aldeia Nova Esperança - trabalha na Aldeia Trindade).

Em um primeiro momento, apresentamos um breve perfil dos professores colaboradores, delineado com base nas informações por eles concedidas nas entrevistas. Em seguida a partir de suas vozes, discutiremos os seguintes aspectos pertinentes ao seu trabalho docente: (i) a organização didática em classes mutisseriadas; (ii) os materiais didáticos utilizados pelos professores; (iii) o ensino da língua indígena na escola.

\section{Perfil dos professores colaboradores}

1 PROFESSOR EDILSON TUPARÍ: é professor há três anos. Mora na aldeia Bom Jesus, onde residem cinco famílias, sendo uma delas Aruá. A língua mais falada é Tuparí. Os Aruá não falam mais sua língua materna e nem a língua Tuparí. Falam português. Edilson trabalha em uma escola localizada em uma aldeia próxima, onde habitam apenas cerca de 20 pessoas, distribuídas em quatro famílias; leciona para alunos Kampé (as crianças Kampé falam o Tuparí; os pais são Kampé e as mães Tuparí). Nessa escola há sete alunos, distribuídos em primeiro, segundo e terceiro anos do Ensino Fundamental. Edilson é o único professor na escola; estudou até a oitava série em escola não indígena e não participou do Projeto Açaí. Atualmente está cursando a Licenciatura Intercultural na Universidade Federal de Rondônia - UNIR, Campus de Ji-Paraná. 
2 PROFESSOR GEOVANE TUPARÍ: mora na aldeia Trindade, cuja população é de aproximadamente 50 pessoas, dentre eles há uma indígena Kampé e uma Arikapú. A primeira língua utilizada na aldeia é a língua Tuparí. As crianças crescem ouvindo e se comunicando na língua Tuparí. A língua portuguesa aprendem a partir dos cinco, seis anos, tanto pelos meios de comunicação, quanto vendo pessoas que chegam de outros lugares e falam apenas o portugês, ou até mesmo para se comunicar com outro povo, outra etnia. Geovane é casado com uma indígena Kampé e, para se comunicar com sua esposa, fala em português. Quando se comunica com seus filhos, só fala em Tuparí. A esposa se comunica com os filhos em português, embora compreenda e saiba falar a língua Tuparí.

3 PROFESSOR ISAÍAS TUPARÍ: mora na aldeia Colorado, onde a maioria dos indígenas é Tuparí. Só tem uma indígena Makuráp, casada com Tuparí. Isaías trabalha na escola desde 1993. A língua mais falada é Tuparí e a segunda língua é português, que é a língua de comunicação com os não-indígenas ou com outros indígenas falantes de outras línguas

4 PROFESSOR JUARI TUPARÍ: mora na aldeia Serrinha há 22 anos e tem 11 anos de sala de aula. Na aldeia, a maioria dos indígenas é Tuparí e há uma pessoa da etnia Makuráp, porém não fala Makuráp; entende e fala um pouco o Tuparí. A primeira língua é o Tuparí e a segunda é a língua portuguesa, usada para a comunicação com os não indígenas e outros indígenas falantes de outras línguas. Juari está cursando o Ensino Médio no Projeto Açaí e trabalha na escola de segunda a sexta-feira, nos turnos matutino e vespertino.

5 PROFESSOR MAURÍCIO TUPARÍ: mora na aldeia Bom Jesus e trabalha na escola Pepo Tuparí há três anos. Anteriormente morava e trabalhava na aldeia Trindade. $\mathrm{Na}$ aldeia Bom Jesus habitam 31 pessoas sendo 28 Tuparí, uma Aruá e um casal em que o marido é mestiço e foi registrado como Tuparí (filho de pai não indígena e de mãe Tuparí) e a mulher é branca. A primeira língua é o Tuparí e a segunda é o Português, usado para a comunicação com a mulher Aruá e com casal, que não falam nem Aruá nem Tuparí.

6 PROFESSOR MORAIS TUPARÍ: mora na aldeia Poção e é professor há 10 anos. Nessa aldeia residem quatro famílias: duas famílias Tuparí, uma família Jiahói e uma Kampé e também há alguns Makuráp que vivem nas proximidades. Os Jiahói e os Kampé não falam mais sua língua materna; entendem um pouco, mas não falam o Tuparí. Na escola, Morais atende alunos das etnias Kampé, Makuráp e Tuparí, do $1^{\circ}$ ao $5^{\circ}$ ano do Ensino Fundamental. Está cursando o Ensino Médio no Projeto Açaí.

7 PROFESSOR RAUL TUPARÍ: mora na aldeia Nova Esperança e trabalha na aldeia Trindade como professor da língua Tuparí para os alunos de sexto ao nono ano. Na aldeia Nova Esperança habita apenas a família de Raul, que é constituída de seis pessoas, das quais cinco são Tuparí e uma (esposa de Raul) é Kampé. A família de Raul se comunica em Tuparí; sua esposa compreende o Tuparí, porém fala a língua portuguesa. Na aldeia Trindade moram cinquenta e quatro pessoas, distribuídas em sete famílias; os indígenas são pertencentes às etnias Tuparí e Kampé. Os Kampé falam a língua portuguesa. 


\section{Aspectos pertinentes ao trabalho docente}

Nesta seção vamos refletir sobre alguns aspectos pertinentes ao trabalho docente dos professores indígenas, tais como: (i) a organização didática em classes multisseriadas; (ii) os materiais didáticos utilizados pelos professores; (iii) o ensino da língua indígena na escola.

\section{A organização didática em classes mutisseriadas}

Classes multisseriadas são classes que "buscam agregar todos os alunos matriculados na unidade escolar independente dos níveis de aprendizagem em uma mesma sala, que por sua vez tem como responsável (na maioria das vezes) um único professor, o qual fica responsável por sua estruturação em série/ano/ ciclo" (Medrado 2012: 140). Em alguns casos, em virtude da falta de orientação, para atuar nestes contextos, o professor reproduz o modelo seriado na própria multissérie, o que acarreta trabalho duplicado, ou até quintuplicado, por se tratar de séries diferentes. Outros professores acabam buscando formas diferentes de atuar em turmas multisseriadas pela própria ausência de orientação ou formação para atuarem em realidades com tamanha diversidade (Parente 2014). De qualquer forma, verificamos que, na maioria das vezes, os professores não têm orientação para atuar neste modelo de turma. Além disso, a autora destaca que nem sempre a multisseriação faz parte da "agenda política educacional" dos Estados, acrescentando que "os currículos e materiais não são pensados para atender turmas multisseriadas e, quando isso acontece, são pensados do ponto de vista de mera adequação."

Com relação à formação dos professor, referindo-se à educação do campo, Medrado (2012) observa que:

Diante da falta de uma política pública que dê conta da dinâmica que constitui as classes multisseriadas, e das mazelas que compõem o cenário sócio educacional das mesmas, torna-se um desafio para qualquer professor ministrar aulas nessas classes. A visão políticopedagógica capaz de lidar com os fatores mencionados é escassa, tornando um agravante na formulação e desenvolvimento das aulas. Sem formação, sem informação sobre as classes multisseriadas, muitos professores e coordenadores se sentem desnorteados sem saber como proceder frente às especificidades da educação do campo e assim também como elaborar e desenvolver uma proposta educacional que atenda às necessidades das séries/anos que compõem a multissérie. Sem esse norte, acabam seguindo o modelo urbanocêntrico, planejando série/ano por série/ano,disciplina por disciplina, desenvolvendo assim também suas aulas. (Medrado 2012: 142)

A atuação (uni)docente em classes multisseriadas, portanto, é um grande 
desafio para os professores brasileiros, agravado pelo fato desse assunto não estar nos currículos dos cursos de licenciatura das universidades. Sobre esse tema, Parente (2014: 64) afirma que:

[...] muitos professores saem dos cursos de licenciaturas sem saber da existência de turmas multisseriadas. Isso é corroborado pela evidência empírica de que os cursos de formação de professores nas várias instuições de ensino superior brasileiras sequer tratam da questão, seja do ponto de vista político-legal, seja do ponto de vista metodológico.

Segundo o Censo Escolar de 2010 cerca de 93.623 turmas no Ensino Fundamental funcionam como multisseriadas ${ }^{7}$, o que representa uma média de $18,14 \%$ da realidade nacional nessa etapa de ensino. É importante evidenciar que as populações a que se destinam as classes multisseriadas são populações socialmente desfavorecidas e, portanto, marginalizadas: camponeses, quilombolas, ribeirinhos e os povos das florestas, nos quais se incluem os indígenas; além disso, podemos encontrar classes multisseriadas na Educação de Jovens e Adultos - EJA, ofertada para as populações das periferias citadinas mais carentes, que não tiveram oportunidade de obter sua escolarização na idade dita regular.

Em se tratando do processo de formação de professores e, ainda, considerando os professores indígenas, podemos dizer que há muito pouca ou quase nenhuma discussão a respeito de formas de atuação em contextos educacionais com a complexidade verificada em turmas multisseriadas, sendo assim, somente diante da dura realidade é que os professores vão se constituindo e construindo formas de superar as dificuldades e neste processo tornando-se professores.

Os pesquisadores Terciana Vidal Moura e Fábio Josué Souza dos Santos (2012), analisando o trabalho docente no contexto de classes multisseriadas e as estratégias usadas pelos professores para construir práticas mais autônomas, afirmam que:

[...] os professores de classes multisseriadas constroem saberes a partir de suas experiências, de suas histórias de vida e estes saberes, construídos em suas lidas, revestem-se numa perspectiva contrahegemônica, pois potencializa um fazer pedagógico que subverte as orientações de cunho tecnicista emanadas das políticas oficiais nacionais e mesmo do planejamento pedagógico instituído no âmbito das Secretarias Municipais de Educação. Elas precisam ser fortalecidas e não desconsideradas no processo de formação destes professores, para que robusteçam sua capacidade criativa e sua autonomia pedagógica. Assim, para formar o professor que possa desenvolver um trabalho

7 Disponível em: https://novaescola.org.br/conteudo/138/como-organizar-o-ensino-emclasses-multisseriadas, acesso em 15/07/2018. 
pedagógico voltado para a realidade das classes multisseriadas com mais autonomia e pertinência, antes de qualquer outra iniciativa, é preciso pensar num outro processo de formação de docente. (Moura e Santos 2012: 79).

Vejamos de que maneira os professores indígenas dizem a respeito da construção de suas práticas pedagógicas nas classes multisseriadas das escolas indígenas Tuparí. Vamos ouvir as suas vozes:

EDILSON - [...] Eu estudei fora da aldeia e eu peguei o ritmo do branco né? assim o ensinamento do branco, assim na sala de aula. Então, a minha disciplina, quando eu comecei a trabalhar, foi naquele ritmo, assim, separado, né? [...] língua portuguesa e matemática na segunda e geografia e ciências na terça... [...] a aula de língua materna sempre foi na quinta-feira. [...] Eu trabalho junto, mas só que cada atividade é diferente! [...] No caso assim, do primeiro ano, primeira série, né? menino pequeno, eu tenho um aluno; ai do segundo tem dois; terceiro ano tem quatro, né? Então, quando é uma atividade assim de figuras, de palavras, de frases, eu coloco assim... na língua materna... eu coloco os sete... só pra mim discutir aquilo lá, junto com eles, porque assim eu acho é melhor e eles entendem melhor, também, tudo junto.... eles gostam...eles gostam de acompanhar, porque sozinho... ele se sente assim... eu não sei... eu acho que eles ficam com vergonha, porque os outros ficam olhando pra ele. Agora, tudo junto eles participam bem.

GEOVANE - [...] Eu trabalho com primeiro ao quinto ano as disciplinas língua materna, língua portuguesa, ciências, matemática, história, geografia, artes, ritos e mitos, educação física... todas essas disciplinas. [...] Atualmente eu tô com... 12 alunos. [...] sendo cinco do primeiro ano, né? Pré... e três do terceiro anos e dois do quarto e dois do quinto ano. [...] Eu trabalho com aluno do primeiro ao quinto tudo junto, no mesmo horário.

ISAÍAS - Eu...escolho uma disciplina pra mim trabalhar [...]. Ai essa disciplina eu divido. Eu pego, por exemplo, ciências. Aí, a ciência, eu pego um tema. Um só. Aí, na atividade eu divido pra cada série. Uns vão fazendo desenho, outros vão fazendo formação de palavra, os pequenininho, outros vão produzindo frase, outros vão produzindo texto. Assim eu achei melhor trabalhar junto com eles. Assim eles aprendem junto, né? [...] Eu tenho a primeira, segunda, quarto e quinto ano... Tudo junto... no mesmo horário. Só que ... uma lousa diferente. Um quadro, né? uma lousa tá aqui, pra outra série, e a outra ao lado. Ai eu vou correndo... atendo aqui, atendo aqui... Mas a gente cansa... mas não tem outro... outro jeito. [...] Escolhe um tema, no qual eu dou a explicação pra eles. $\mathrm{Na}$ atividade é que eu faço a divisão pra cada... pra cada série.

JUARI - Dividi a... a horário. Porque são uns...dezessete alunos... De séries iniciais, né? Do primeiro, segundo e terceiro ano, eu trabalho de manhã. Ai a tarde, das uma até às... de tarde, eu trabalho com quarto e quinto ano. Então.. é assim, né? É muito pesado, mas a gente tem de enfrentar, né? [...] As outras disciplinas eu trabalho é....português, né? no primeiro, primeiro... no primeira hora, né? Aí segunda hora já é outra disciplina, matemática. 
MAURÍCIO - É.. de primeiro eu trabalhava seis... seis aula, né? por dia... na semana. Só que depois eu... eu diminuí. Porque... pra mim eu achei muito pesado, não é? O horário, também... [...] Agora eu trabalho bem.. é... na segunda-feira, né? eu trabalho língua português, na terça, matemática, quarta ciência e... sexta eu trabalho com língua materna e história. [...] Aí, na outra semana eu trabalho com geografia e novamente língua materna. Isso aí a gente tá trabalhando mais né? com essa língua materna, pra poder... pra que os alunos aprendem mais, né? sobre a língua. [...] Quando trabalho com ciências, com geografia e história, eu... faço só desenho, né? Assim...pra primeiro e terceiro. Agora pra quarta eu faço leitura e eles faz leitura, também. [...] Ali tem cinco alunos, né? que eu trabalho com eles. Só que são... é... seriado também, né? Tem primeiro ano, terceiro e quarto. Não tem segundo ano... Então, ali eu trabalho com vários... com várias disciplinas, né? Igual daqui da cidade. Só que a gente inclui a língua materna pra... pra alfabetizar nossos alunos.[...] Todo mundo junto. Então... Primeira... quando eu vou trabalhar com eles, eu trabalho com letra inicial, também, do nome dos animais, objetos... na língua. Com aluno de primeiro ano. Agora, com o terceiro ano eu já trabalho com a palavra e... o aluno faz, né? [...] Só com o quarto ano eu trabalho com texto. E figura mesmo.... Na língua Tuparí.. e na língua portuguesa também.

MORAIS - Eu trabalho de primeira e segundo ano. Tenho 20 alunos. [...] segunda-feira eu trabalho de português e matemática, né? ai a terça-feira eu trabalho com ciências e geografia; na quarta-feira eu trabalho de... história e... história... e a ciência de novo. Ai sexta-feira eu volto a trabalhar... não... quinta-feira eu volto a trabalhar é... com língua portuguesa e matemática.... Aí na sexta-feira eu trabalho só com a língua materna com eles, fazendo nosso... arte...

RAUL - Eu trabalho, com aluno de sexto ao nono ano. Eu trabalho na língua materna, né? É... dai tanto eu trabalho na língua materna... às vezes eu uso assim... o texto em português, né? Eu faço dois... duas aula, vamo dizer. Eu faço... peço pra eles elaborar um texto, depois eu faço transcrição na língua, porque é bilíngue, né? hoje...Até para os surdos, que não falam a língua Tupari entender e facilitar o trabalho pra eles. [...] Agora se eu... se tivesse... se fosse só aluno Tuparí, ai era mais... eu dava aula assim direto na língua Tuparí, né? [...] Nesse sentido, é Kampé. Ai eu explico um pouco em português e... mas eles tão desenvolvendo bem... [...] É... com sexto e sétimo ano, eu trabalho assim, tipo com pequenas... texto.. pequeno... frase, formação de frase, desenhos, é... e os nomes... trabalho com o sexto ano...

Podemos depreender das falas dos professores três questões cruciais: (i) o ensino dividido em caixinhas, ou seja, o ensino dividido em disciplinas, (ii) as turmas multisseriadas, ou seja, o ensino dividido em séries e (iii) a presença de alunos pertencentes a diferentes etnias na mesma sala de aula. São questões complexas que devem ser consideradas no planejamento dos cursos de formação inicial e continuada. Os professores possuem experiências diversas de escolarização: alguns estudaram nas escolas das aldeias, outros em escolas do campo (chamadas escolas rurais) outros nas escolas cidade, outros estudaram no curso de formação de professores I Projeto Açaí e podemos notar que eles trazem essa experiência de escolarização para sua prática. 
Assim, as suas experiências como estudantes aliadas às experiências docentes contribuem para que os professores busquem estratégias para desenvolver suas práticas pedagógicas, organizando-se didaticamente, buscando alternativas para exercerem seu trabalho docente, ainda que tenham como pano de fundo o modelo da educação escolar não indígena: organizam horários e disciplinas, selecionam temas, elaboram diferentes atividades para as diferentes séries existentes nas classes, organizam o espaço físico e até mesmo a lousa, a fim de atender aos diferentes alunos.

Alguns professores conseguem superar as questões ensino por disciplinas, usando como estratégia a aula integrada: selecionam um tema e, após a discussão coletiva, cada série procede a uma diferente atividade: desenhos, letra inicial, nomes de animais/objetos e formação de palavras para o primeiro ano; produção de frases e pequenos textos para alunos do segundo e terceiro anos; produção e tradução de textos para alunos a partir do quarto ano. Um elemento complicador é a existência de alunos pertencentes a outras etnias, o que dificulta a comunicação pedagógica e o ensino da língua Tuparí. Por outro lado, essas línguas também reivindicam espaço na escola, caso de Makuráp, Kampé e Aruá.

\section{Os materiais didáticos utilizados pelos professores}

Segundo Esteve (1991), “os professores que encaram a renovação pedagógica do seu trabalho vêem-se, frequentemente, limitados pela falta do material didático necessário e de recursos para adquiri-lo" (Esteve 1991: 106. In: Novoa 1991).

Os professores Tuparí, como tantos outros professores indígenas de outras etnias, também se ressentem da falta de material didático, especialmente na língua Tuparí:

EDILSON - Tem uma cartilha que fizeram, né? Uma cartilha Tuparí [...] É... Mas só que naquela cartilha tem algumas palavras erradas, que... escreveram. Aí, eu quase eu não uso... Aquele lá não uso não. É difícil eu usar... Então, o trabalho que eu faço, assim, pra mim passar pra eles, é... eu mesmo produzo, né? [...] É... frases, palavras e... figuras de animais, de objetos... [...] Ai, depois que eu faço todo aquele trabalho, que eu produzo é... figuras, ai eu peço pra eles colocar tudo em... na língua materna. Ai eles escrevem. Escrevem bem.

GEOVANE - Não tem material. Então... o critério que eu tô usando pra alfabetizar é assim... é... é com as figuras, com a natureza, que as crianças já conhecem, né? Então, o objetivo dessa alfabetização é que as crianças já são da natureza, já sabem o significado, assim, é... de certas coisas, por exemplo, é fruta. É plantas, o nome... eles... eles praticamente sabem um pouco, então, eu... eu tô utilizando é...essa metodologia, né? pra...pra facilitar, né? E a gente faz a pesquisa, faz pesquisa de campo, leva os alunos pro pátio, e a gente volta pra... pra sala, e faz um desenho que representa... representa as figuras que a gente vê e... a gente faz uma reflexão sobre o significado de cada coisa, né?, o que eu acho assim um ponto positivo, pro aluno, né? já começar a se expressar...nas 
coisas que ele faz.

ISAÍAS - Material didático a gente improvisa do não indígena, né? A gente seleciona, pra trabalhar, até porque nós não tem ainda, né? material específico pro indígena, aí a gente improvisa. [...] Mas... a gente acredita que a gente vai produzir matéria. Nós temos bastante material produzido, tá escrito, falta só a gente organizar ela, né? publicar...E esse que nós iniciamos...fazendo... eu acredito que logo a gente vai ter esse material pra trabalhar.

JUARI - A gente utiliza o livro didático da SEDUC, né? Mas... pra ensinar a língua materna, a gente produz o texto, né? A gente escreve, através de desenho, da ilustração.... e aí a gente passa pra eles, pros alunos, esses de séries iniciais, né? Agora, pro primeiro ano, é só desenho mesmo. Aí, é... como eles são, assim... eles entendem um pouco, assim, como que é o início da...do nome desse ilustração, aí só se coloca a letra, só... né? [...] Agora, o segundo ano já começa a escrever, formar o nome completo, mas... não muito completo, mas, assim... pela... variação.... aí varia. [...] No terceiro ano já ensina frase, já começa... envolver bastante. E aí, quarto ano, ele mesmo já pode fazer o desenho e produzir o texto. Ai o quinto ano também ... [...]

MAURÍCIO - Eu uso o livro, né? didático..acompanho o livro didático...da SEDUC... do MEC...[...]. São vários. De todas as matérias... A gente pega, né? pra poder trabalhar por semana, aquela matéria. Às vezes eu levo eles, né? também pro mato pra.... trabalhar no campo.

MORAIS - Material didático... a gente... a SEDUC consegue pra gente, né? Com os livros.... [...] na língua Tuparí tem que o Isaías mais o Raul fizeram aquele lá, faz tempo, e entregaram pra gente... então, é com aquilo que eu tô... tentando trabalhar.

RAUL - Não tem material didático na língua. Até agora a gente tá tentando fazer, né? Por isso que é importante nos dedicar... elaborar é... um trabalho, né? Nós tamos tentando... é...não tem... por exemplo... mas temos aquela primeira cartilha, né? mas aquilo é pra criancinha, né? Pra... pros alunos mais adiantado tem que ser o texto, maior, de dez linha, quinze linha, que... leva ao conhecimento, né? Isso que é importante.

Diante da falta de material específico, os professores indígenas utilizam os livros didáticos fornecidos pelo MEC para as disciplinas curriculares. Salientamos que os livros fornecidos pelo MEC são os mesmos utilizados nas escolas situadas em áreas urbanas, não trazendo nenhuma especifidade ou adequação para as escolas indígenas. Como estratégias, alguns professores que não seguem o livro didático do MEC "improvisam" suas aulas, segundo eles, selecionando temas e conteúdos a serem aplicados para suas turmas.

Quanto ao ensino da língua Tuparí, existe uma cartilha de alfabetização elaborada pelos professores Tuparí e organizada pela professora Lucy Seki: a cartilha "Tuparí 'Ema'ê". Esse material didático foi fruto de um projeto coordenado pela Associação Agrária dos Povos Indígenas do Rio Branco. Naquele período, a professora Rosângela Reis assessorou a associação para 
encaminhar um projeto para o MEC. O projeto foi aprovado e com o recurso foi possível contratar a assessoria da professora Lucy Seki, que organizou o material e a FUNAI posteriormente o publicou. Durante os anos posteriores, os professores Tuparí realizaram várias mudanças na escrita de sua língua e precisaram atualizar e reformular o livro. A atualização e a reformulação, segundo informações dos professores, foram realizadas por eles com assessoria de um linguista, no ano de 2015. Ainda não houve publicação desse novo material, mas os professores já possuem cópia do livro mais atualizado.

Os professores, de modo geral, também demonstram a intenção de elaborar e publicar materiais mais adequados para os alunos maiores, já que a falta de material de leitura na língua Tuparí dificulta o letramento nessa língua. Diante da falta de material didático para o ensino de língua, os professores constroem estratégias tais como: o uso de desenhos e ilustrações, pesquisa e trabalho de campo.

O tema da falta de material de leitura é abordado há muito tempo nos cursos de formação de professores indígenas no Estado de Rondônia, entretanto ainda não se criou uma política de produção de material didático no Estado. Atualmente a Ação Saberes Indígenas na Escola discute esse assunto e está com vários projetos em andamento para a produção de materiais de alfabetização e de leitura específicos à realidade das escolas. Além disso, os professores Tuparí também têm buscado, por iniciativa própria, parceria com a Universidade para estudar a sua língua e construir materiais específicos para o ensino na escola. Demostram autonomia e são conscientes do seu importante papel no diálogo entre a tradição e a educação escolar.

\section{O ensino da língua indígena na escola}

EDILSON - Bom... estudar a língua eu acho muito interessante, né? É muito importante porque é... praticando essa língua, esse idioma, a gente tá... tá praticando a nossa identidade, né? É... nós não tamos perdendo ali... enquanto nós tamos praticando. Eé importante também é que, daqui uns tempos, as crianças eles podem falar também na língua, né? Porque é... muitos já quase não falam porque os pais, as mães incentivam a criança assim a falar português e ai já começa a crescer só ouvindo aquilo e aí vai abandonando a língua indígena. Então, eu acho muito interessante a gente alfabetizar e praticar a língua materna desde pequeno. Então, os meus alunos, eles gostam muito.... principalmente assim na pesquisa; pesquisa de plantas medicinais, ai depois pesquisa objetos, animais... então tudo isso eu trabalho com eles.

GEOVANE - [...] E... eu vi a prioridade pra... pra língua que é falada, né? como a língua Tuparí, né? É porque logo que eu comecei, eu dava mais importância pra língua portuguesa, porque eu achava que essa língua é mais valorizada fora da aldeia, né? então a minha preocupação era focalizado, né? na potência da língua... assim... no mundo. Aí, a partir do momento que eu entendi que tanto a língua portuguesa quanto a língua materna é importante pra quem é falante, tanto pra valorizar, eu vi, então eu reservei esse espaço 
maior pra língua materna.

ISAÍAS - Pra mim, que a escola tá fortalecendo a língua, porque a gente discute né? sobre isso... Eu sei da importância da língua, né? É o lugar de... a gente tá sempre conversando com as crianças, né? Sensibilizando eles. Então, a escola, ela ajuda fortalecer a língua.

JUARI - A escola tá valorizando os dois (Tuparí e português). Porque, hoje, a gente sabe que é... nós somos muito cobrados pra não esquecer de falar a língua materna, sabe? Então, ai a comunidade disse pra gente que a gente tem que ensinar, e eles aprender escrever e falar, né? E aprender duas línguas ao mesmo tempo, né? E língua portuguesa eles quer que aprenda também pra eles se defender... [...] pra colocar reivindicação, né?

RAUL - Eu ensino o Tuparí pra todo mundo. É... Aí o Tuparí é como a segunda língua pra eles, os alunos Kampé. Pros Tuparí mesmo, como é a primeira língua, né? a gente tenta trabalhar os dois.

Muito embora a falta de material didático específico e diferenciado para a educação escolar indígena seja fato, os professores buscam fortalecer o ensino de língua indígena na escola. E esse ensino tem basicamente uma vertente: a língua indígena como fator de afirmação identitária. O ensino de língua portuguesa tem por objetivo a comunicação com os não indígenas e com outros povos não falantes do Tuparí. Para ensinar a língua indígena, muitas vezes se valem de pesquisa, por ser uma estratégia largamente difundida nos mais variados cursos de formação. A esse respeito, Grupioni (2003: 14) afirma que

o professor indígena deve ser formado como um pesquisador não só dos aspectos relevantes da história e da cultura do seu povo, mas também dos assuntos considerados significativos nas várias áreas de conhecimento. Dessa atividade de pesquisa e estudo podem resultar materiais utilizáveis tanto no processo de formação desse professor como na escola, para o uso didático com seus alunos

Os professores indígenas, de modo geral, se revelam como grandes e exímios coletores de dados. Mas é preciso condições para que construam seus próprios caminhos teórico metodológico para sistematização e análise desses dados. Neste sentido, os professores Tuparí têm se preocupado com o estudo da sua língua e, por meio da Universidade, tem sido possível realizar cursos sistemáticos sobre a gramática da língua Tuparí. Vale ressaltar a importância dos trabalhos por eles desenvolvidos, pois constituem registro e documentação não apenas da língua, mas também de outros elementos da cultura.

Com relação ao ensino da língua Tuparí, há duas questões importantes que devemos levar em consideração: primeiro, a escrita da língua Tuparí é recente e ainda não há um uso sitemático da lígua escrita, a não ser na escola. Alguns 
professores estão aprendendo a escrita e isso vem se consolidando nos estudos que eles desenvolvem sobre sua língua; a segunda questão refere-se ao ensino do Tuparí em contextos tão diversos, ou seja, cada escola na Terra Indígena Rio Branco tem uma realidade sociolinguística específica, principalmente no que diz respeiro ao número de etnias presente nas escola, ou a língua de instrução que é utilizada. Por esses motivos nos parece que os professores, com relação ao o ensino da língua indígena, têm se posicionado em um local onde ficam seguros de estar neste momento, ou seja, utilizado-se de estratégias que dominam para o ensino da língua, tais como listas de palavras (nomes de plantas, objetos, animais e outros), estruturação de sentenças simples e pequenos textos. Mas acreditamos que, com o aprofundamento do estudo do Tuparí e a produção de material didático que contemple as várias realidades sociolinguísticas das escolas, os professores poderão consolidar o ensino/aprendizado da língua Tuparí na TI Rio Branco.

Uma outra questão que vale destacar é que, segundo os professores, muitas crianças já não são estimuladas pelos pais a falar o Tuparí como língua materna. Então, a escola assume sozinha este papel. E sabemos que a língua ensinada na escola em grande parte difere da língua de uso. Isso vale também para as aquelas línguas que servem como segunda língua, no caso, a língua portuguesa (que acabou por se impor e causar o extermínio de muitas línguas indígenas brasileiras).

Ainda que os professores valorizem o ensino da língua Tuparí nas escolas, é necessário que continuem a aprofundar os conhecimentos liguísticos sobre sua língua por meio de estudos coletivos entre os professores para que possam aplicar esses conhecimentos ao ensino de línguas.

Os professores Tuparí, motivados pela preocupação e vontade própria de estudar sua língua, têm realizado oficinas sobre a língua desde 2012. No ano de 2018, no mês de abril, ocorreu a última oficina cujo objetivo era o de aprofundar o estudo da gramática Tuparí. Mas o trabalho com esses povo, mesmo que pequeno, considerando-se tudo o que ainda é necessário fazer tem se configurado uma excessão no que diz respeito a formação linguística dos professores indígenas no Estado de Rondônia.

Vale salientar que esses professores atuam em comunidades bilíngues e que, a sua maneira, procuram desenvolver, como se pode observar nas suas falas, um ensino bilíngue. Refletindo sobre a formação de professores indígenas que atuam nesses contextos, D'Angelis (2003: 38-39) assevera que:

A formação de professores para atuar em uma situação de comunidade bilíngüe e em um programa de ensino bilíngüe impõe (ou requer) uma capacitação específica desses professores em: - língua materna (o que não quer dizer, apenas, "saber falar" a língua); - língua portuguesa (idem); - ensino de línguas; - bilingüismo e ensino bilíngüe. A 
capacitação em língua materna, em língua portuguesa e no ensino de línguas supõe instrumentos próprios da linguística que devem ser incorporados na formação do professor (noções fundamentais de fonética e fonologia, morfologia, sintaxe, semântica, lingüística textual e sociolingüística).

Compartilhamos do pensamento de D'Angelis, pois é fato que os egressos dos cursos de formação de professores indígenas (e também dos não indígenas) têm pouco domínio de conhecimentos em fonética/fonologia, morfologia, sintaxe, semântica, linguística textual e sociolinguística. A realidade da educação escolar indígena brasileira, porém, é que muitos professores indígenas não possuem formação em nível superior, outros ainda nem terminaram o magistério indígena. Pensar em uma realidade ideal onde o professor dominasse todas as áreas da linguagem necessárias para um ensino de línguas com exelência, neste momento, seria realmente utópico.

Mesmo enfrentando dificuldades diante dos conhecimentos em linguística, os professores Tuparí têm investido na produção de textos na sua língua, como estratégia de ensino, muitos dos quais resultaram em material de leitura. Isto é muito positivo. Ao poucos vão inserindo as análises dos textos, na medida em que vão compreendendo como a língua se organiza, mas isso demanda tempo e formação nos estudos de sua língua e de metodologias de ensino de línguas.

Os anos iniciais do Ensino Fundamental vêm sendo contemplados com o ensino da língua Tuparí e os professores, com sua experiência e com o conhecimento que possuem no uso de sua língua, têm conseguido desenvolver um bom trabalho. Entretanto, quando esse ensino tem prosseguimento nos anos escolares subsequentes do Ensino Fundamental e do Ensino Médio, o conteúdo é muito limitado (no que concerne aos aspectos de descrição e uso da língua) e a produção textual, embora, em muitos casos, rica de histórias e memórias culturais, é circunscrita aos limites da escola e pouco contribui para o letramento da comunidade. Os professores tem consciência dessa realidade e tem buscado soluções para superar as dificuldades.

Ainda considerando a formação dos professores indígenas enquanto pesquisadores que possam contribuir com a preservação e revitalização de suas línguas, Cabral, Sampaio e da Silva Sinha (2016: 57) dizem que "the role of the indigenous teachers and researchers is fundamental, and new policies need to be developed in order to support the training of indigenous linguists at a high level of formal education". . Em adesão às palavras das autoras citadas, acrescentamos que, além da formação de professores indígenas pesquisadores, a formação

\footnotetext{
8 “o papel dos professores e pesquisadores indígenas é fundamental, e novas políticas precisam ser desenvolvidas para apoiar a formação de linguistas indígenas em um alto nível de educação formal”. (Trad. Wany B. A. Sampaio).
} 
para atuar nesses contextos também deve alcançar os professores formadores de professores indígenas; compreendemos que os professores formadores de professores indígenas necessitam dos conhecimentos em linguística apontados por D'Angelis.

Percebe-se, entretanto, que, no processo de formação dos professores indígenas, por mais que nos nossos discursos esteja sempre presente o lema do "específico e diferenciado", ainda falta uma preocupação das instituições que atuam diretamente com a formação dos professores indígenas em observar o quão específico e diferenciado é esse processo; neste sentido, é necessário buscar soluções novas e não criar novos enquadramentos em situações já existentes. Sabemos que isso não é fácil, porém, se nos falta, enquanto formadores, a habilidade necessária para o exercício dessa prática em nosso próprio trabalho docente, devemos buscar construí-la. Uma parte dessa não habilidade pode se pautar na falta de conhecimento. Nesse sentido, vale lembrar o que tão bem pondera Santos (1975) a respeito da educação como processo:

A educação como processo deve ser pensada como a maneira pela qual os membros de uma dada sociedade socializam as novas gerações, objetivando a continuidades dos valores e instituições consideradas fundamentais. Assim sendo, quando os membros de sociedades tribais ficam sujeitos a uma sistemática escolar patrocinada e inspirada pela sociedade nacional envolvente, passamos a uma situação particular onde o processo educacional procura assegurar, antes de tudo, os objetivos da sociedade dominante (Santos 1975: 53-54).

As palavras de Santos (1975) não podem ser desconsideradas, pois mesmo com o advento da nossa Constituição Federal (1988), do Referencial Curricular para as Escolas Indígenas (1998), dos Referenciais para a Formação de Professores Indígenas (2002) e tantos outros documentos e políticas que garantem os direitos de uma educação específica e diferenciada, a educação escolar indígena ainda vive assujeitada ao modelo da educação escolar da sociedade não-indígena.

Os professores indígenas, entretanto, buscam construir seus saberes docentes a partir da sua própria experiência, da troca de experiências com outros professores e da sua própria prática docente e lutam para mudar o quadro de não autonomia na educação escolar indígena. A exemplo, podemos afirmar a atuação dos professores Tuparí na Ação Saberes Indígenas na Escola é percebida como uma das experiências de maior autonomia nesse tempo de formação continuada. O esforço da Ação, em parceria com os professores Tuparí (orientadores, pesquisadores e cursistas) em sistematizar e produzir materiais didáticos próprios - tais como o Livro dos Peixes (no prelo) e o vídeo documentário Chicha Tuparí (disponível no YouTube), entre outros - demonstram que alguns caminhos estão sendo traçados e percorridos para a melhoria da qualidade de sua educação escolar. 


\section{Considerações Finais}

Neste trabalho tivemos dois objetivos: i) dar voz aos professores indígenas e b) estimular nos pesquisadores e professores formadores uma reflexão acerca da constituição dos saberes dos professores indígenas a partir do trabalho docente por eles vivenciado. A partir das vozes dos professores Tuparí, buscamos perceber como/quando se constituem seus saberes profissionais, considerandose a caracterização existencial, social e pragmática dos saberes docentes, bem como a sua dimensão temporal.

Das vozes dos professores selecionamos como elementos relevantes para a discussão proposta: (i) a organização didática em classes multisseriadas; (ii) os materiais didáticos utilizados pelos professores; (iii) o ensino da língua indígena na escola. Vimos que os professores enfrentam grandes desafios em relação e esses três aspectos (entre outros que não foram discutidos neste trabalho), considerando-se: a complexidade da realidade sociolinguística das escolas; o fato de estarem ao mesmo tempo aprendendo e ensinando sua língua; as formações que recebem ainda não serem suficientes para suprir suas demandas; a falta de um acompanhamento pedagógico mais especializado para as suas realidades. Não podemos esquecer que grande parte das dificuldades enfrentadas pelos professores indígenas é porque as políticas públicas educacionais para os povos indígenas estão distantes de atender as suas verdadeiras necessidades.

Os professores da T.I Rio Branco, mais especificamente os professores Tuparí, têm uma consciência muito grande da importância de estudar sua língua e do seu papel como professor em contribuir para o fortalecimento da língua por meio da escrita. A autonomia dos professores com relação ao estudo de sua língua é uma realidade animadora. Por iniciativa própria, os Tuparí buscaram estabelecer parceria com a Universidade e têm conseguido que se desenvolvam estudos sistemáticos sobre a língua Tuparí e, consequentemente, a produção de materiais para utilizar na escola, nos diversos níveis de aprendizagem; além disso, há uma grande preocupação com relação à documentação de sua língua e de sua cultura. Mesmo que tenham recebido vários apoios de projetos e ações no sentido de contribuir com a formação desses professores, foram eles que primeiramente apresentaram suas necessidades.

No presente texto, fizemos uma reflexão a partir de suas próprias falas e trouxemos um pouco da realidade do ensino nas escolas, da falta de material didático, de suas dúvidas em relação à complexidade de uma realidade multisseriada, multilíngue, multiétnica, multi tantas outras coisas. Diante de tal realidade, o que devemos fazer? Dividir os alunos para facilitar o trabalho docente? Aprender formas de juntar os alunos sem perder o foco na necessidade de cada um? Pensamos ser uma questão bastante complexa e não teríamos uma única resposta, mas com certeza a reflexão dialógica em torno da prática docente é um caminho interessante para se trilhar. Neste sentido, o processo de escrita deste artigo nos ajudou muito, contribuindo para nossa própria reflexão e para 
a construção de nossos próprios saberes enquanto professores formadores de professores indígenas.

Conforme reflete Tardif (2002), os saberes que os professores utilizam para sua prática docente não se limitam ao conhecimento dos conteúdos escolares especializados; o conhecimento acadêmico é fundamental, mas os saberes profissionais também envolvem tudo o que está relacionado ao trabalho do professor. É importante também considerar os valores sociais, culturais e afetivos na construção desses saberes.

Assim, os saberes profissionais dos professores indígenas vão se constituindo ao longo do tempo, no exercício da profissão. Eles valorizam muito a formação acadêmica, os cursos de formação de professores, mas sabem que a formação inicial é uma parte importante da sua formação profissional, mas não é suficiente para tantas demandas que as diferentes realidades trazem. Por isso, está presente em suas vozes a aplicação de suas histórias de vida social e escolar na sala de aula, envolvendo também fatores emocionais e afetivos. Os professores menos experientes buscam também aprender com os mais experientes, nos momentos que criam para dialogarem sobre a sua prática e em suas observações; além disso, vão também se constituindo a partir de experiências vivenciadas, no dia-a-dia, de sua própria prática docente.

\section{Referências}

Alves, Poliana Maria. Análise Fonológica Preliminar da Lingua Tuparí. (Dissertação de Mestrado). Universidade de Brasília, 1991.

. O Léxico do Tuparí: uma proposta de dicionário bilíngue. (Tese de Doutorado). São Paulo: Universidade Estadual Paulista "Júlio de Mesquita", Faculdade de Ciências e Letras - Campus de Araraquara, 2004.

Brasil/MEC/SEF. Referenciais para a formação de professores indígenas. Secretaria de Educação Fundamental. Brasília: MEC/SEF, 2002.

- Referencial curricular nacional para as escolas indígena.s Secretaria de Educação Fundamental. Brasília: MEC/SEF, 1998.

Cabral, Ana Suelly Arruda Câmara Cabral, Sampaio, Wany Bernardete de Araujo and da Silva Sinha, Vera. Indigenous languages policies em Brazil: training indigenous people as teachers and researchers. In: Filipovic, Luna and Pütz, Martin (ed.). IMPACT studies in language and society, Volume 42: Endangered languages an languages in danger: issues of documentation, policy, and language rights. Amsterdam/Philadelphia: John Benjamins Publishing Company, 2016, 45-59.

Caspar, Franz. Tuparí (Entre os índios, nas florestas brasileiras). Trad. de M. N. de Souza Queiroz. São Paulo: Ed. Melhoramentos, 1953.

D'Angelis, Wilmar da Rocha. Propostas para a Formação de Professores Indígenas no Brasil. In: Em Aberto (Experiências e Desafios na Formação de Professores Indígenas no Brasil), Brasília, v. 20, n. 76: 34-43, fev. 2003. 
Esteve, José M. Mudanças Sociais e Função Docente. In: NÓVOA, A. (Org.), Profissão Professor. Porto: Porto Ed., 1991.

Grupioni, Luís Donisete Benzi. Experiências e Desafios na Formação de Professores Indígenas no Brasil. In: Em Aberto, Brasília, v. 20, n. 76: 13-18, fev. 2003.

Fonseca, Mary Gonçalves. Casa de escrever no papeo: a escola Tuparí da Terra Indígena Rio Branco, Rondônia. (Dissertação de Mestrado). Programa de Pós Graduação e Desenvolvimento Regional e Meio Ambiente. Universidade Federal de Rondônia. Porto Velho, 2011.

Isidoro, Edineia Aparecida et al. Ação Saberes Indígenas na Escola - RIES-RO/AC: Relatório parcial das atividades periodo de novembro de 2013 a julho de 2014 (Relatório).

Martins, Marilene, Como Organizar o Ensino em Salas Multisseriadas, disponível em: https://novaescola.org.br/conteudo/138/como-organizar-o-ensino-em-classesmultisseriadas, acesso em 15/07/2018.

Medrado, Carlos Henrique de S. Práticas pedagógicas em classes multisseriadas. In. Entrelaçando. Revista Eletrônica de Culturas e Educação. No 7, V. 2, Ano III (2012) Set.-Dez. p.133-148. Caderno Temático V. Educação, Escolas e Movimentos Sociais do/no Campo.

Melatti, Julio Cezar. Áreas Etnográficas da América Indígena Mamoré-Guaporé. Retocado em 2011. Capítulo 25: Mamoré-Guaporé. DAN-ICS-UnB 70910-900 Brasília, DF. Disponível em: www.juliomelatti.pro.br/areas/25guapore.pdf

Meireles, Denise Maldi. Guardiães da Fronteira: Rio Guaporé, século XVIII. Petrópolis: Vozes, 1989.

Moura, Terciana Vidal e Santos, Fábio Josué Souza. A pedagogia das classes multisseriadas: uma perspectiva contra-hegemônica às políticas de regulação do trabalho docente. In: Debates em Educação. Vol. 4, nº 7. Maceió, Jan.-Jul. 2012.

Rodrigues, Aryon Dall' Igna. Línguas Brasileiras: para o conhecimento das línguas indigenas. São Paulo: Loyola, 1986.

Rodrigues, Aryon Dall' Igna; Caspar, Franz. Esboço da Gramática da Língua Tuparí. In: CABRAL, Ana Suelly Arruda Câmara; Silva, Ariel Pheula do Couto; Lopes, Jorge Domingues (Org.) Esboço da Gramática da Língua Tuparí. Brasília: LALLI, [1957] 2017: 11-100.

Rosa, Ana Cristina Silva. Classes multisseriadas: desafios e possibilidades. In: Educação \& Linguagem. Ano 11. N. 18: 222-237, Jul.-Dez. 2008.

Sampaio, Wany Bernardete de Araujo; Isidoro, Edineia Aparecida; Paula, Luciana Castro de. Ensino de segunda língua: uma experiência com professores indígenas no estado de Rondônia. Comunicação Oral - I Congresso Internacional sobre estudos interculturais e Seminário de avaliação do PIBID Diversidade. Dourados: UFGD, 2014. (Artigo no Prelo). 
Santos, Sílvio Coelho dos. Educação e Sociedades Tribais. Porto Alegre: Movimento, 1975.

Seki, Luci. Aspectos Morfossintáticos do Nome em Tuparí. In: Aryon Rodrigues e Ana Suelly A. C. Cabral (Org.). Atas da ANPOLL. Belém: Editora Universitária UFPA, tomo I, 2002: 298-308.

Tardif, Maurice e Raymond, Danielle. Saberes, tempo e aprendizagem do trabalho no magistério. In. Educação \& Sociedade, ano XXI, n 73, Dezembro/00: 209-244.

Tardif, Maurice. Saberes docente e formação profissional. Petrópolis: Vozes, 2002.

Tuparí, Raul Pat Ware. OTE MA'Ẽ - Reflexões Sobre a Escrita da Lingua Tuparí. 2015, 84 fl. Monografia de Conclusão de Curso, Educação Básica Intercultural, Universidade Federal de Rondônia - Campus de Ji-Paraná, 2015.

Vander Velden, Felipe Ferreira. Os Tupí em Rondônia: diversidade, estado do conhecimento e propostas de investigação. In: Revista Brasileira de Linguística Antropológica. Vol. 2, n. 1:115 - 123. UnB; LALLI. Jul. 2010. 